\title{
ANALISIS KEKUATAN SAMBUNGAN GESER GANDA ENAM JENIS KAYU PADA BERBAGAI SESARAN MENURUT DIAMETER DAN JUMLAH BAUT
}

\author{
Double Shear Connections Analysis of Six Wood Species at Various Displacement Based on Diameter \\ and Number of Bolts
}

\author{
Sucahyo Sadiyo ${ }^{1 凹}$, Imam Wahyudi', Fengky Satria Yoresta ${ }^{2}$, Nurhasanah² dan Muhammad Sholihin² \\ ${ }^{1}$ Departemen Hasil Hutan Fakultas Kehutanan, Institut Pertanian Bogor, Kampus Darmaga, Bogor \\ ${ }^{2}$ Alumni Departemen Hasil Hutan Fakultas Kehutanan IPB
}

\begin{abstract}
This research aims to determine the effect of double shear connection strength of six types of timber in various displacement based on diameter and the number of bolts. Six types of wood used are bangkirai, punak, meranti, sengon, bintangur and kapur. Double shear connection consists of the main member (wood) and side member (steel plate) with bolts connected. The average moisture content of sengon, meranti, bintangur and bangkirai are relatively similar (about $12 \%$ ), while kapur and punak are slightly higher at around $14 \%$. In contrast, the average density of six wood species are greatly vary ranging from the lowest sengon $0.26 \mathrm{~g} \mathrm{~cm}^{-3}$, to the highest $0.82 \mathrm{~g} \mathrm{~cm}^{-3}$ of bangkirai wood. The total load and load per bolt on double shear connection using bolts connector are influenced by the type of wood, diameter and number of bolts. There is a strong tendency that the higher specific gravity or density of the wood makes higher total load and load per bolt on double shear connection for each displacement. In addition, an increasing number of bolts makes the total load increased. On the other hand, it decreases load per bolts for each of bolts diameter. The use of 10 pieces of $7.9 \mathrm{~mm}$ diameter bolts on double shear connection for almost all type of wood produces the highest average total load compared to the other bolt diameter for both displacement $1.5 \mathrm{~mm}$ and $5 \mathrm{~mm}$. In the same connection displacement the highest load per bolt is still obtained from using $7.9 \mathrm{~mm}$ bolt diameter but with the use of 4 pieces of bolts for almost all types of wood with the exception for punak and bitangur showing the highest values are obtained from 6 pieces of bolts. Bangkirai wood, kapur, punak, bintangur and meranti can be used as the main member in double shear connection by using bolt with diameter $6.4 \mathrm{~mm}, 7.9 \mathrm{~mm}$ and $9.5 \mathrm{~mm}$ because of fulfilling the requirements of PKKI (1961).
\end{abstract}

Key words: Bolts, double shear connections, displacement, total load, load per bolt

\section{PENDAHULUAN}

Kayu sebagai bahan konstruksi struktural dan non struktural masih digunakan secara luas bagi masyarakat pedesaan pada khususnya dan masyarakat perkotaan umumnya. Hal ini disebabkan kayu memiliki banyak keuntungan sebagai bahan bangunan apabila dibandingkan dengan material lain, seperti baja, beton dan lain sebagainya. Pada sisi lain kayu yang tersedia dan dijual di pasaran masih sangat terbatas dimensinya baik ukuran panjang maupun dimensi penampangnya. Namun

\footnotetext{
Diterima: 23 Maret 2012; Disetujui: 22 Juni 2012

$\square$ Penulis korespondensi (corresponding author): sucahyoss@gmail.com
}

untuk keperluan konstruksi struktural selain harus memenuhi persyaratan keteguhan atau kekuatan memikul beban rencana, kekakuan dan kestabilan struktur, kayu juga harus memiliki bentangan yang cukup panjang. Oleh karena itu, perlu dilakukan disain dan teknik penyambungan dengan berbagai alat sambung untuk dapat mencapai suatu bentang struktur yang diinginkan.

Menurut Tular \& Idris (1981) sambungan kayu merupakan titik kritis atau terlemah yang terdapat pada titik hubung atau elemen dari suatu bangunan struktural. Salah satu bentuk sambungan yang harus diperhitungkan dengan seksama adalah sambungan tarik. Hal ini dikarenakan pada ukuran penampang yang besar kekuatan sambungan tarik biasanya rendah sehingga sulit untuk mengimbangi 
besarnya kekuatan batang utamanya. Komponen pembentuk sambungan sangat memengaruhi kekuatan dari sambungan kayu yang dihasilkan. Komponen tersebut adalah batang kayu yang akan disambung, alat sambung, dan bentuk sambungan yang dibuat (Suryokusumo et al., 1980). Batang kayu yang disambung dapat memengaruhi kekuatan sambungan karena terdapat perbedaan sifat fisik dan mekanik dari setiap jenis kayu. Begitupun dengan alat sambung yang digunakan, jumlah dan ukuran alat sambung sangat memengaruhi kekuatan sambungan.

Kebiasaan para engineer di Amerika Serikat menggunakan baut untuk disain sambungan pada bangunan struktural dilakukan dengan pertimbangan bahwa gaya-gaya yang disalurkan relatif besar (Breyer et al., 2007). Alat sambung yang digunakan dalam penyambungan dapat berupa pelat sambung dan baut. Pelat sambung akan membentuk sambungan dengan mudah dan diharapkan dapat meningkatkan kekuatan sambungan. Baut merupakan salah satu alat sambung mekanik yang dapat digunakan dalam pembuatan sambungan kayu. Penggunaan baut sebagai alat sambung telah banyak digunakan dan dapat diaplikasikan dalam konstruksi kayu yang menerima beban besar, namun masih terdapat kekurangan dari alat sambung baut yaitu efisiensi rendah dan deformasi besar (Yap, 1997). Oleh karena itu diperlukan suatu metode yang mudah untuk mengetahui besar beban yang mampu diterima oleh sambungan baut, sehingga

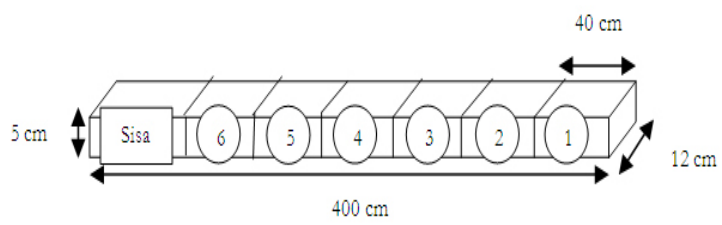

Gambar 1. Pola pemotongan batang kayu (Nurhasanah, 2010)

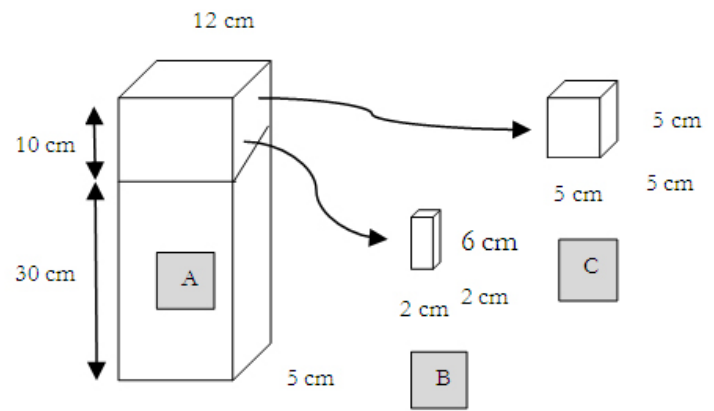

Gambar 2. Pola pemotongan contoh uji (Nurhasanah, 2010) dapat meningkatkan efisiensi dan meminimalisasi deformasi.

Variabel yang dapat digunakan untuk menduga besarnya kekuatan sambungan terhadap beban tarik yang bekerja adalah jumlah dan diameter alat sambung baut serta jenis kayu yang digunakan. Berdasarkan uraian diatas, maka dilakukan penelitian untuk mengetahuai perilaku dan menentukan besar pengaruh jumlah dan diameter baut terhadap kekuatan kekuatan sambungan geser ganda batang kayu dengan pelat baja jenis kayu.

\section{METODE PENELITIAN}

Kayu yang digunakan dalam penelitian ini terdiri atas enam jenis kayu perdagangan Indonesia yang memiliki perbedaan kerapatan dan atau berat jenis (BJ) yang cukup signifikan. Ketiga jenis kayu tersebut adalah kayu bangkirai (Shorea laevis), kayu punak (Tetramerista glabra), kayu meranti (Shorea spp), sengon (Paraserianthes falcataria (L). Nielsen), bintangur (Calophyllum inophyllum L.) dan kapur (Dryobalanops sp). Kayu diperoleh dalam bentuk batang dan atau balok berukuran tebal $5 \mathrm{~cm}$, lebar $12 \mathrm{~cm}$ dan panjang $400 \mathrm{~cm}$. Untuk masing-masing jenis digunakan 7 batang kayu tanpa membedakan antara kayu gubal dan kayu teras. Sebelum kayu dipotong menjadi contoh uji, terlebih dahulu dilakukan pengeringan di dalam kilang pengering selama kurang lebih 12 hari untuk mendapatkan kadar air kering udara.

Alat sambung yang digunakan berupa baut terdiri atas tiga ukuran diameter, yaitu 6,4; 7,9 dan 9,5 mm dengan panjang masing-masing $10,16 \mathrm{~cm}$. Bahan penelitian lainnya adalah pelat baja yang dalam penelitian ini pelat tersebut telah digunakan sebelumnya oleh Sriyanto (2009). Ukuran pelat baja adalah $1,5 \mathrm{~cm} \times 12 \mathrm{~cm}$ dengan panjang $30 \mathrm{~cm}$. Pelat yang tersedia sebelumnya telah terdapat lubang, kemudian lubang-lubang tersebut diperbesar sesuai dengan besarnya ukuran diameter baut yang digunakan sebagai pelat sambung. Banyaknya lubang yang dibuat yaitu 8 dan 10 lubang. Pelat baja dengan 8 lubang hanya digunakan untuk penggunaan baut sebanyak 8 baut. Sedangkan untuk pelat baja dengan 10 lubang dapat digunakan untuk penggunaan baut sebanyak 4, 6 dan 10 baut.

Kayu yang telah dikeringkan ke kadar air kering udara kemudian dipotong dari semula berukuran 5 $\mathrm{cm} \times 12 \mathrm{~cm} \times 400 \mathrm{~cm}$ menjadi batang-batang dengan 
ukuran lebih kecil yaitu $5 \mathrm{~cm} \times 12 \mathrm{~cm} \times 40 \mathrm{~cm}$. Dengan demikian untuk setiap jenis kayu diperoleh 6 batang kayu (Gambar 1). Batang yang tersisa digunakan untuk mengganti contoh uji yang memiliki cacat. Pada masing-masing batang berukuran $5 \mathrm{~cm} \times 12$ $\mathrm{cm} \times 40 \mathrm{~cm}$ dilakukan pemotongan kembali untuk digunakan sebagai contoh uji. Pola pemotongan contoh uji disajikan pada Gambar 2.

Penyambungan kayu menggunakan pelat baja dilakukan secara mekanik dengan cara melekatkan dua buah pelat baja pada kedua sisi lebar batang yang akan disambung. Sebelum penyambungan dilakukan, untuk menghindari kayu pecah akibat penetrasi alat sambung baut ke dalam batang kayu dengan pelat baja, dan untuk mempermudah memasukkan alat sambung baut tersebut, maka dilakukan pengeboran pada kayu dan pelat baja. Pengeboran pada pelat baja disesuaikan dengan ukuran diameter baut, sedangkan pada kayu digunakan diameter bor yang lebih besar dari diameter baut. Hal ini dilakukan dengan maksud untuk membatasi perlemahan tanpa mengurangi daya ikat kayu dengan pelat baja terhadap alat sambung baut sehingga sambungan tetap dapat dipertahankan. Alat sambung baut dimasukkan kedalam lubang pada pelat baja-batang kayu-pelat baja yang telah disiapkan, kemudian dilakukan pengencangan menggunakan mur setelah ujung baut tembus pada ketiga komponen sambungan tersebut agar sambungan kuat dan rapat. Pengaturan geometri sambungan geser ganda batang kayu dengan pelat baja dan alat sambung baut (satuan $\mathrm{cm}$ ) disajikan pada Gambar 3.

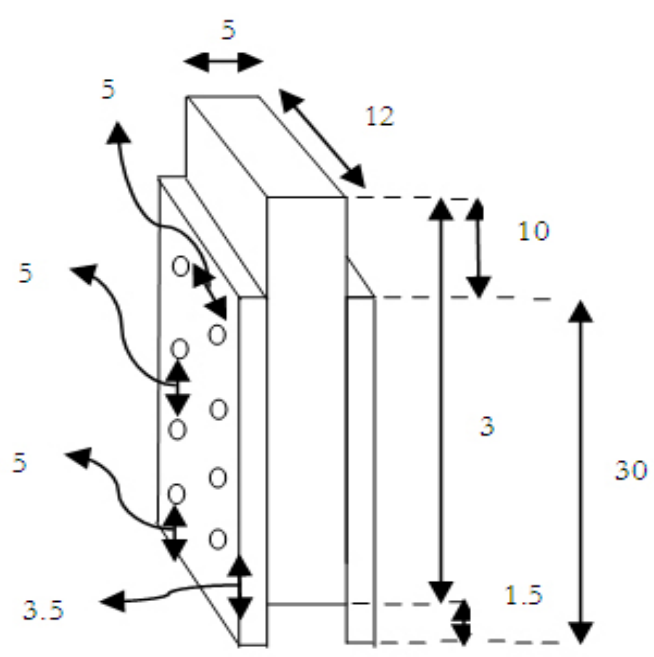

Gambar 3. Pengaturan Geometri sambungan geser ganda (Nurhasanah, 2010)
Setelah dibuat contoh uji sambungan geser ganda dengan pelat baja dan baut, kemudian dilakukan uji tekan pada sambungan dengan arah gaya/beban tekan tegak lurus sumbu memanjang baut dan sejajar dengan sisi panjang contoh uji. Pada saat uji tekan tersebut dilakukan yang menjadi penahan beban adalah baut dan kekuatan kayu itu sendiri. Perilaku dan fenomena pada pengujian dengan cara menekan contoh uji ini diasumsikan sama dengan pengujian tarik hanya saja yang membedakan keduanya adalah arah gayanya.

Pengujian sifat fisik meliputi BJ, kerapatan ( $\rho)$ dan kadar air (KA) serta sifat mekanis meliputi pengujian tekan maksimum sejajar serat atau Maximum Crushing Strength (MCS) dilakukan dengan menggunakan Universal Testing Machine merk Instron series IX version 8.27.00 mengacu pada standar ASTM D 143 (2005) tentang Standard Methods of Testing Small Clear Specimens of Timber. Pengujian tekan maksimum sejajar serat tersebut dilakukan dengan memberikan beban secara perlahan-lahan hingga contoh uji mengalami kerusakan $\left(P_{\text {maks }}\right)$. Beban diberikan pada arah sejajar serat kayu dengan kedudukan contoh uji vertikal, dan beban tersebut merupakan beban maksimum yang dapat diterima oleh contoh uji. Nilai MCS dihitung dengan menggunakan rumus MCS = $P_{\text {maks }} / A$, dimana $A$ adalah luas penampang.

Pengujian kekuatan sambungan geser ganda batang kayu terhadap beban tekan menurut diameter dan jumlah baut dilakukan dengan menggunakan Universal Testing Machine merk Shimadzu UH100A. Pengujian kekuatan sambungan geser ganda didasarkan atas standar ASTM D 5652-95 (2002) yang dimodifikasi. Pengujian ini dilakukan dengan pemberian beban tekan pada sambungan batang kayu geser ganda itu sendiri hingga batang kayu tersebut mengalami kerusakan. Dalam pengujian kekuatan sambungan geser ganda tersebut nilai yang diukur dinyatakan dalam beban total dan beban per baut. Perhitungan beban per baut dan beban total sambungan geser ganda dilakukan pada beberapa tingkat sesaran tertentu yaitu sesaran 0,80 mm (Standar Australia), 1,50 mm (PKKI-1961) dan 5,00 mm (beban rusak). Besarnya rata-rata kekuatan per baut pada sambungan geser ganda $(P)$ ditentukan dengan membagi beban total pada sesaran yang diinginkan $(B)$ dengan jumlah baut (n).

Untuk membandingkan karakteristik dan perilaku sambungan geser ganda menurut jenis 
kayu, jumlah dan diameter baut maka data diolah dengan menggunakan software microsoft excel 2007. Sebaran data rataan sifat fisik dan mekanis sambungan geser ganda tersebut ditampilkan dalam bentuk histogram. Analisis data pengamatan dilakukan dengan menggunakan metoda deskripsi kuantitatif.

\section{HASIL DAN PEMBAHASAN}

\section{Sifat Fisis Kayu}

Penelitian kekuatan sambungan ini memperlihatkan bahwa kadar air dari enam jenis kayu yang diteliti terdiri atas dua kelompok, kelompok dengan kadar air relatif rendah, yaitu kayu sengon $14,27 \%$, meranti $12,31 \%$, bintangur $12,40 \%$, bangkirai $12,46 \%$ dan kelompok dengan kadar air agak tinggi, yaitu kapur $14,44 \%$ dan kayu punak sebesar $14,85 \%$. Kadar air dari keenam jenis kayu tersebut berada di bawah kadar air titik jenuh serat (30\%), dan dapat dipastikan telah mencapai kadar air kesetimbangan (KAK). Panshin et al. (1964) menyatakan bahwa apabila kayu tidak lagi melepaskan atau menyerap air, maka kayu berada dalam kondisi kesetimbangan dengan lingkungan. Kadar air pada kondisi tersebut dinamakan KAK yang seringkali dianggap sama dengan kadar air kering udara. KAK dipengaruhi oleh keadaan lingkungan dimana kayu itu digunakan, terutama suhu dan kelembaban relatif udara di sekitarnya. Yap (1997) menyebutkan bahwa pada umumnya kayu-kayu di Indonesia yang kering udara mempunyai kadar lengas (kadar air) antara 12-18\% atau rata-rata 15 $\%$. Menurut Haygreen \& Bowyer (1993), perbedaan kadar air kayu dipengaruhi oleh berbagai faktor, diantaranya jenis kayu, tempat tumbuh dan umur dari pohon.

Kerapatan menunjukkan massa zat kayu per satuan volume. Hasil penelitian menunjukkan sebaran rata-rata kerapatan enam jenis kayu yang diteliti sangat bervariasi. Kayu bangkirai memiliki kerapatan tertinggi yaitu sebesar $0,82 \mathrm{~g}$ $\mathrm{cm}^{-3}$, disusul kayu kapur $0,82 \mathrm{~g} \mathrm{~cm}^{-3}$, punak 0,78 $\mathrm{g} \mathrm{cm}^{-3}$, bintangur $0,54 \mathrm{~g} \mathrm{~cm}^{-3}$, meranti $0,36 \mathrm{~g} \mathrm{~cm}^{-3}$ dan terendah pada kayu sengon $0,26 \mathrm{~g} \mathrm{~cm}^{-3}$. Nilai kerapatan kayu dapat menggambarkan kekuatan kayu dimana nilai tersebut berbanding lurus, dengan semakin besarnya nilai kerapatan suatu kayu maka kayu tersebut akan semakin kuat. Nilai kerapatan kayu tersebut sejalan dengan BJ kayu, dimana kayu bangkirai memiliki BJ tertinggi $(0,73)$ disusul kayu kapur 0,72 ; punak 0,68 ; bintangur 0,48; meranti 0,32 dan terendah pada kayu sengon 0,23 . BJ kayu merupakan salah satu sifat fisik kayu yang sangat penting untuk menggambarkan seberapa besar kekuatan dan ketahanan kayu dalam menerima gaya atau beban dari luar. Sadiyo (1989) mengatakan bahwa perbedaan BJ kayu pada dasarnya dapat disebabkan oleh adanya perbedaan struktur anatomi kayu yang meliputi macam, jumlah dan pola penyebaran pori (saluran pembuluh), parenkim, jari-jari kayu dan saluran interselluler. Disamping kadar air dan zat ekstraktif sebagai komponen penyusun kayu, faktor lainnya yang justru paling dominan memengaruhi $\mathrm{BJ}$ atau kerapatan kayu adalah tebal dinding sel atau zat kayu, dimana semakin tebal dinding sel kayu maka makin tinggi pula BJ atau kerapatan kayu tersebut. Menurut Bowyer et al. (2003) besarnya BJ kayu berbeda-beda tergantung struktur kayu dan perbandingan antara jumlah dinding sel dengan rongga kayu. Nilai BJ biasanya bertambah dengan berkurangnya kadar air di bawah titik jenuh serat.

\section{Sifat Mekanis Kayu}

\section{Kekuatan Tekan Maksimum Sejajar Serat}

Sebaran rataan kekuatan tekan maksimum sejajar serat dari yang tertinggi hingga terendah berturut-turut adalah kayu bangkirai $\left(646 \mathrm{~kg} \mathrm{~cm}^{-2}\right)$, disusul kayu kapur $489 \mathrm{~kg} \mathrm{~cm}^{-2}$, punak $519 \mathrm{~kg} \mathrm{~cm}^{-2}$, bintangur $404 \mathrm{~kg} \mathrm{~cm}^{-2}$, meranti $289 \mathrm{~kg} \mathrm{~cm}^{-2}$ dan terendah pada kayu sengon $231 \mathrm{~kg} \mathrm{~cm}^{-2}$. Apabila dikaitkan dengan kadar air kayu meranti yang memiliki kadar air terendah, hasil ini berlawanan dengan teori yang menyebutkan bahwa pada umumnya kekuatan kayu akan bertambah seiring dengan berkurangnya kadar air di bawah kadar air titik jenuh serat. Namun pada sisi lain pengaruh kerapatan dan atau BJ pada penelitian ini jauh lebih besar dibandingkan kadar air dalam memberikan kontribusi terhadap MCS. Dengan demikian kayu meranti yang memiliki kekuatan tekan maksimum terendah, berbanding lurus atau sejalan dengan kerapatan dan BJ kayu tersebut yang rendah diantara tiga jenis kayu yang diuji. Menurut Courney (2000) perilaku tekan bahan padat seluler seperti kayu diantaranya dipengaruhi oleh tebal dinding sel dan distribusi kerapatan kayu tersebut. Beery et al. (1983) menyatakan bahwa perilaku elastis lebih tergantung pada kerapatan daripada karakteristik anatomi kayu. 
Perbedaan kekuatan tekan antarjenis kayu ini menandakan bahwa disamping adanya perbedaan tebal dinding sel, mungkin juga disebabkan ikatan antarsel penyusunnya terutama antarsel jari-jari kayu dan antara sel jari-jari dengan sel didekatnya diduga kurang kuat, sehingga ketahanan dalam mendukung atau menahan beban tekan menjadi rendah. Namun dengan demikian menurut Sadiyo (2010) kerapatan atau BJ bukanlah merupakan satu-satunya peubah atau variabel utama semata dalam menentukan kekuatan suatu jenis kayu. Walaupun secara umum terdapat tendensi yang sangat kuat bahwa kerapatan berbanding lurus dengan kekuatan kayu.

\section{Kekuatan Sambungan Geser Ganda}

\section{Beban Total}

Pola sebaran rataan beban total sambungan geser ganda enam jenis kayu menurut sesaran 1,5 $\mathrm{mm}$ dan 5,0 mm disajikan pada Gambar 4 dan 5 . Secara umum beban total $(\mathrm{kg})$ sambungan geser ganda pada sesaran 1,5 mm (Gambar 4) semakin meningkat dengan meningkatnya BJ kayu yang dicerminkan oleh jenis kayu. Kayu sengon yang memiliki kerapatan paling rendah garis beban totalnya berada di bawah atau lebih rendah dibandingkan dengan kayu lainnya, kemudian berturut-turut semakin meningkat diikuti oleh kayu meranti, punak, bintangur, bangkirai dan kapur. Hal ini disebabkan kayu dengan BJ tinggi serat-serat kayunya mampu menjepit baut dengan kuat dan mampu menahan beban yang dihasilkan dengan tinggi pula. Selain itu dapat pula disebabkan oleh lebih tingginya kekuatan tekan maksimum sejajar serat pada kayu yang memiliki BJ tinggi (bangkirai dan kapur) dibandingkan dengan kayu lainnya. Pada penggunanaan paku berdiameter cukup besar $(7,9$ dan $9,5 \mathrm{~mm}$ ) walaupun punak memiliki kerapatan jauh lebih tinggi dibandingkan jenis bintangur namun beban total kedua jenis kayu tersebut berbanding terbalik. Fenomena tersebut sejalan dengan kayu bangkirai dan kapur. Perbedaan beban total sambungan geser ganda dengan baut pada dua jenis kayu tersebut, disamping disebabkan oleh perbedaan kadar air (KA punak > bintangur) juga dikarenakan jenis kayu bintangur dan kapur diduga banyak mengandung serat terpadu (interlock grain). Serat perpadu pada kayu bersifat meningkatkan beban lateral baut dibandingkan kayu berserat lurus.

Tanpa memerhatikan diameter baut dan jenis kayu, rataan beban total sambungan geser ganda menggunakan 4, 6, 8 dan 10 baut pada sesaran 1,5 $\mathrm{mm}$ berturut-turut adalah 1.278, 1.699, 2.220 dan $2.518 \mathrm{~kg}$. Dengan demikian berdasarkan jumlah baut, secara rata-rata terdapat kecenderungan umum bahwa beban total sambungan geser ganda akan semakin besar dengan meningkatnya jumlah baut yang digunakan (Gambar 4), kecuali pemakaian baut berdiameter besar $(\varnothing=9,5 \mathrm{~mm})$ beban total sambungan dengan 6 baut untuk jenis kayu kapur dan 8 baut untuk jenis bintangur dan punak lebih besar dibandingkan pemakaian jumlah baut di atasnya. Penyimpangan-penyimpangan kecil yang tidak lazim ini lebih disebabkan oleh kondisi fisik kayu yang digunakan saat penelitian tidak dapat dihindarkan, misalnya adanya cacat kayu, perbedaan-perbedaan kadar air, kerapatan

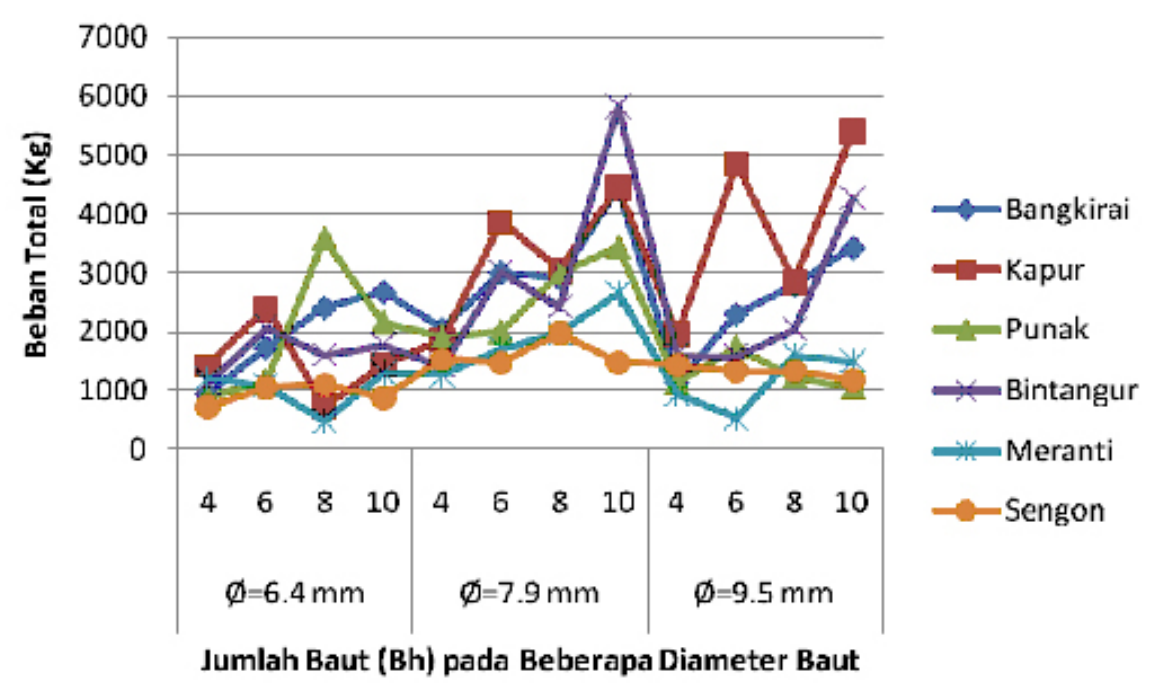

Gambar 4. Rataan beban total $(\mathrm{kg})$ sambungan geser ganda enam jenis kayu menurut diameter dan jumlah baut pada sesaran $1,5 \mathrm{~mm}$ 


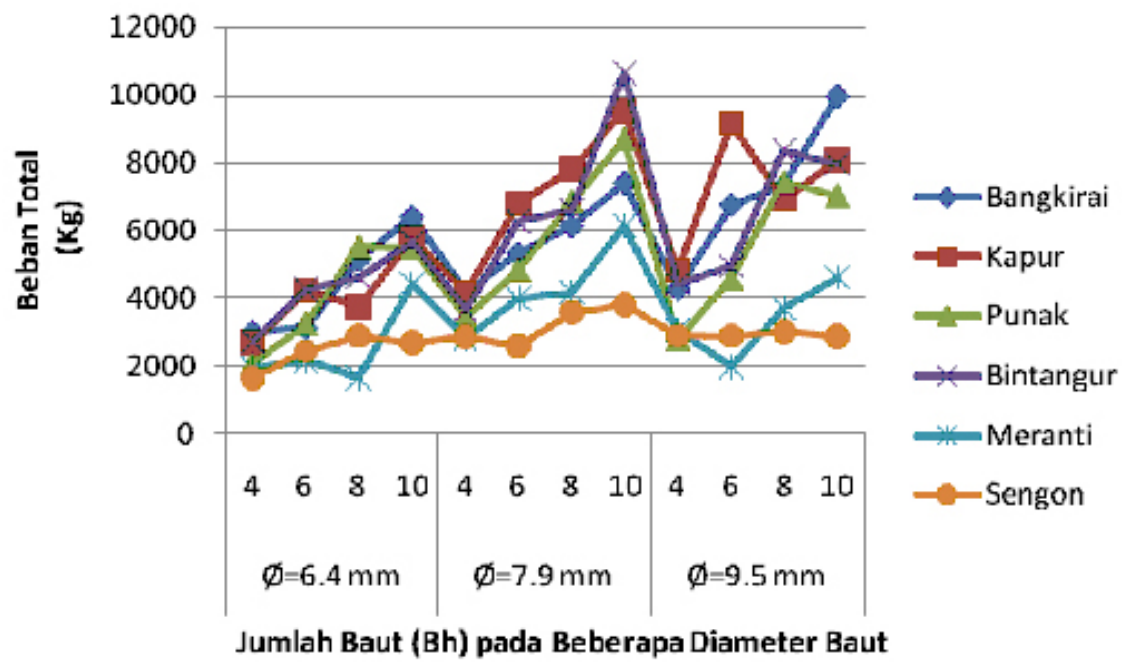

Gambar 5. Rataan beban total $(\mathrm{kg})$ sambungan geser ganda enam jenis kayu menurut diameter dan jumlah baut pada sesaran $5,0 \mathrm{~mm}$

dan BJ kayu. Penggunaan baut berdiameter $7,9 \mathrm{~mm}$ menghasilkan beban total $(2.531 \mathrm{~kg})$ lebih tinggi dan berbeda nyata dibandingkan baut berdiameter $6,4 \mathrm{~mm}(1.638 \mathrm{~kg})$ dan bahkan dengan baut besar berdiameter $9,5 \mathrm{~mm}(1.618 \mathrm{~kg})$. Menurut Nurhasanah (2010), hal ini diduga karena dengan pemakaian diameter baut yang besar akan menyebabkan tingginya perlemahan yang terjadi pada sambungan, akibat lebih banyaknya luasan permukaan kayu yang rusak dan menyebabkan terjadinya pemadatan kayu, sehingga baut berdiameter 7,9 mm menghasilkan nilai beban total yang lebih tinggi daripada baut berdiameter 9,5 $\mathrm{mm}$. Namun diduga pula bahwa dengan pemakaian diameter baut yang kecil pada sambungan kurang mampu untuk menahan beban dengan baik, sehingga baut berdiameter $6,4 \mathrm{~mm}$ lebih rendah dalam menghasilkan nilai beban total sambungan dibandingkan dengan baut berdiameter $7,9 \mathrm{~mm}$.

Perilaku sebaran rataan beban total yang diperlihatkan pada sambungan geser ganda untuk sesaran 1,5 mm (Gambar 4) tidak jauh berbeda dengan sesaran 5,0 mm (Gambar 5). Hanya saja beban total yang dihasilkan dari sesaran $5,0 \mathrm{~mm}$ lebih besar sekitar 1,5-2,0 kali dari sesaran 1,5 $\mathrm{mm}$. Perubahan yang cukup signifikan terjadi pada penggunaan 8 baut berdiameter $6,4 \mathrm{~mm}$ pada sesaran $5,0 \mathrm{~mm}$ dari jenis bintangur serta penggunaan 10 baut juga berdiameter $6,4 \mathrm{~mm}$ dari jenis bintangur, kapur dan punak beban totalnya meningkat drastis dibandingkan beban total pada sesaran $1,5 \mathrm{~mm}$. Fenomena yang sama juga terjadi pada penggunaan 8 baut berdiameter $7,9 \mathrm{~mm}$ dari jenis kayu bintangur, kapur dan bangkirai beban totalnya dari sesaran $1,5 \mathrm{~mm}$ ke $5,0 \mathrm{~mm}$ meningkat drastis dibandingkan pemakaian jumlah baut 6 buah. Perubahan beban total tersebut dikarenakan pada sesaran 5,0 mm telah terjadi kerusakan serat di sekitar lubang baut (telah memasuki daerah elastis) dimana dinding-dinding sel sebagai komponen utama pendukung kekuatan kayu mengalami pemadatan.

Tanpa memerhatikan diameter baut dan jenis kayu, rataan beban total sambungan geser ganda menggunakan $4,6,8$ dan 10 baut pada sesaran $5,0 \mathrm{~mm}$ berturut-turut dari terendah sampai dengan tertinggi adalah $3.074,4.018,5.333$ dan $6.691 \mathrm{~kg}$. Sedangkan tanpa memerhatikan jumlah baut dan jenis kayu, baut berdiameter 7,9 dan 9,5 $\mathrm{mm}$ menghasilkan beban total yang relatif sama yaitu masing-masing 5.339 dan $5.302 \mathrm{~kg}$ namun lebih tinggi dan berbeda nyata dibandingkan baut berdiameter 6,4 mm (3.697 kg) (Nurhasanah, 2010; Sholihin, 2011). Pada konteks yang disebutkan terakhir, Nurhasanah (2010) mengatakan bahwa dengan pemakaian diameter baut yang besar akan menyebabkan tingginya perlemahan yang terjadi pada sambungan, akibat lebih banyaknya luasan permukaan kayu yang rusak dan menyebabkan terjadinya pemadatan kayu, sehingga baut berdiameter 7,9 dan $9,5 \mathrm{~mm}$ menghasilkan nilai beban total yang lebih tinggi daripada baut berdiameter 6,4 mm. Namun diduga pula bahwa dengan pemakaian diameter baut yang kecil pada sambungan kurang mampu untuk menahan beban dengan baik, sehingga baut berdiameter $6,4 \mathrm{~mm}$ 
lebih rendah dalam menghasilkan nilai beban total sambungan dibandingkan dengan baut berdiameter $7,9 \mathrm{~mm}$.

\section{Beban Per Baut}

Pola sebaran rataan beban total sambungan geser ganda enam jenis kayu menurut sesaran 1,5 dan $5,0 \mathrm{~mm}$ disajikan pada Gambar 6 dan 7. Perilaku sebaran beban total menurut jenis kayu tidak jauh berbeda dengan beban per baut, dimana pola sebaran rataan beban per baut $(\mathrm{kg})$ sambungan geser ganda pada sesaran $1,5 \mathrm{~mm}$ juga semakin meningkat dengan bertambahnya BJ atau kerapatan kayu yang dicerminkan oleh jenis kayu. Kayu sengon yang memiliki kerapatan paling rendah garis beban per bautnya berada dibawah atau lebih rendah dibandingkan kayu lainnya, kemudian semakin meningkat disusul oleh kayu meranti, punak, bintangur, bangkirai dan kapur. Hal ini disebabkan kayu dengan BJ tinggi memiliki dinding sel yang lebih tebal dibandingkan dengan kayu BJ rendah, sehingga serat-serat kayunya mampu mengikat baut dengan kuat dan mampu menahan beban yang dihasilkan dengan tinggi pula. Selain itu dapat pula disebabkan oleh lebih tingginya kekuatan tekan maksimum sejajar serat pada kayu yang memiliki BJ tinggi (bangkirai dan kapur) dibandingkan dengan kayu lainnya.

Pada penggunaan baut berdiameter cukup besar (7,9 dan 9,5 mm) walaupun punak memiliki kerapatan jauh lebih tinggi dibandingkan dengan jenis bintangur namun beban per baut kedua jenis kayu tersebut berbanding terbalik. Fenomena tersebut sejalan dengan kayu-kayu yang memiliki BJ tinggi, seperti bangkirai dan kapur. Perbedaan beban per baut sambungan geser ganda dengan baut pada dua jenis kayu tersebut, disamping disebabkan oleh perbedaan kadar air (KA punak > bintangur) juga dikarenakan jenis kayu bintangur

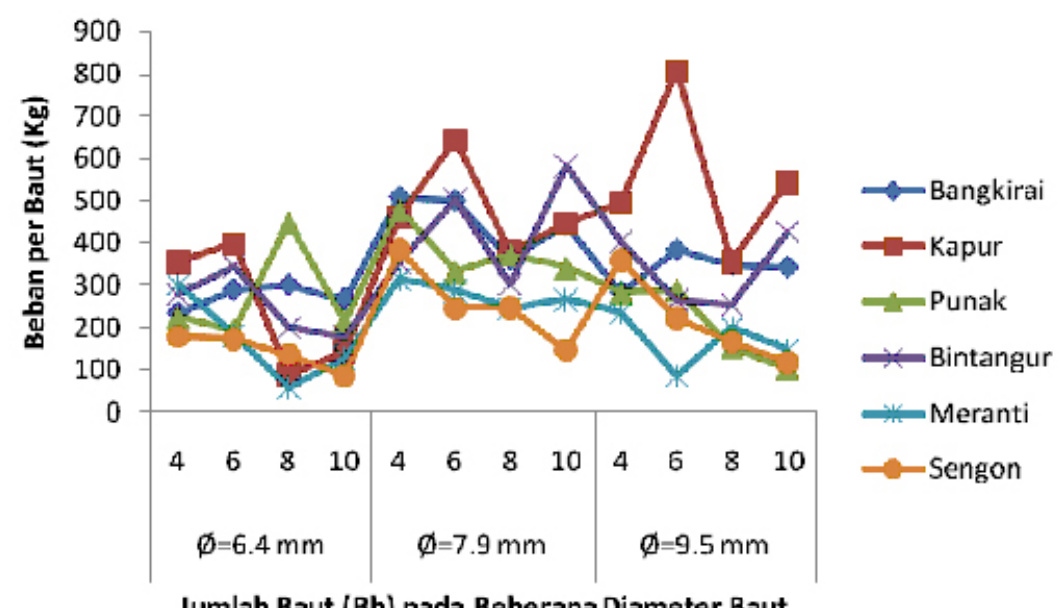

Gambar 6. Rataan beban per baut $(\mathrm{kg})$ sambungan geser ganda enam jenis kayu menurut diameter dan jumlah baut pada sesaran $1,5 \mathrm{~mm}$

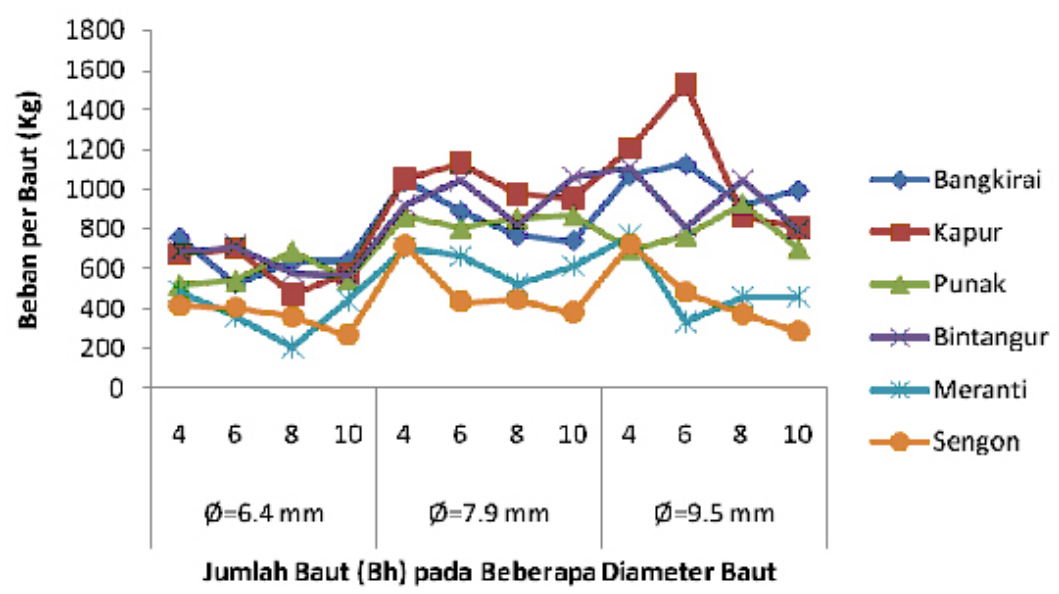

Gambar 7. Rataan beban per baut $(\mathrm{kg})$ sambungan geser ganda enam jenis kayu menurut diameter dan jumlah baut pada sesaran $5,0 \mathrm{~mm}$ 
dan kapur diduga banyak mengandung serat terpadu (interlock grain). Serat perpadu pada kayu bersifat meningkatkan beban lateral baut dibandingkan kayu berserat lurus. Nurhasanah (2010) mengatakan bahwa pemakaian diameter baut yang besar akan menyebabkan tingginya perlemahan yang terjadi pada sambungan, akibat lebih banyaknya luasan permukaan kayu yang rusak dan menyebabkan terjadinya pemadatan kayu, sehingga baut berdiameter $7,9 \mathrm{~mm}$ menghasilkan nilai beban per baut yang lebih tinggi daripada baut berdiameter $9,5 \mathrm{~mm}$. Namun diduga pula bahwa dengan pemakaian diameter baut yang kecil pada sambungan kurang mampu untuk menahan beban dengan baik, sehingga baut berdiameter $6,4 \mathrm{~mm}$ lebih rendah dalam menghasilkan nilai beban per baut sambungan dibandingkan dengan baut berdiameter $7,9 \mathrm{~mm}$.

Berdasarkan faktor jumlah baut, pada sesaran 1,5 mm (Gambar 6) pola sebaran rataan beban per baut terutama untuk kayu-kayu yang memiliki BJ rendah (sengon dan meranti) sampai sedang (terutama punak) memperlihatkan suatu kecenderungan yang sangat kuat dimana semakin besar pemakaian jumlah baut justeru semakin rendah beban perbautnya. Sebaliknya kayu-kayu ber BJ tinggi memperlihatkan pola sebaran beban per baut yang fluktuatif. Ketika sesaran sambungan ditingkatkan menjadi $5 \mathrm{~mm}$ (Gambar 7) pola sebaran beban per baut untuk semua jenis kayu yang diteliti cenderung mendekati perilaku kayu BJ rendah. Perbedaan pola sebaran tersebut diduga kuat disebabkan karena pada sesaran 1,5 mm penggunaan seluruh jumlah baut (4-10 bh) pada kayu-kayu BJ rendah telah merespon pembebanan dengan sempurna, sedangkan pada kayu BJ tinggi hanya sebagian baut saja yang telah memikul beban yang diberikan. Ketika sesaran dinaikkan menjadi $5 \mathrm{~mm}$, disamping seluruh baut telah bekerja juga terjadi pemadatan kayu di sekitar lubang baut.

Perilaku sebaran beban per baut menurut jumlah baut ini sangat berbeda apabila dibandingkan dengan penggunaan alat sambung paku. Surjokusumo et al. (1980) mengatakan bahwa ratarata kekuatan per paku akan meningkat dengan meningkatnya kerapatan kayu tetapi cenderung konstan dengan bertambahnya jumlah paku. Menurut PKKI-1961 dalam Yap (1997) dikatakan bahwa apabila dalam suatu barisan terdapat lebih dari 10 buah paku, maka kekuatan paku harus dikurangi dengan $10 \%$ dan jika lebih dari
20 batang harus dikurangi dengan $20 \%$. Secara tersirat pernyataan ini menunjukan bahwa sampai pemakaian paku kurang dari 10 batang pada suatu sambungan paku memperlihatkan bahwa kekuatan paku tidak perlu dikurangi atau kekuatan per paku relatif sama atau seragam.

Berdasarkan pendekatan perhitungan kekuatan sambungan tampang dua yang dimuat pada PKKI (1961) yang diklasifikasikan ke dalam 3 golongan, maka besarnya rataan kekuatan atau beban per baut untuk kayu golongan I, II dan III masing-masing untuk bangkirai, punak dan meranti adalah sebesar 779,640 dan $393 \mathrm{~kg}$. Rataan beban per baut untuk sesaran $5 \mathrm{~mm}$ hasil penelitian ini sedikit lebih tinggi $(693 \mathrm{~kg})$ namun jauh lebih rendah $(283 \mathrm{~kg})$ untuk sesaran 1,5 $\mathrm{mm}$ dibandingkan beban per baut yang diatur dalam PKKI (1961) yaitu sebesar $604 \mathrm{~kg}$.

Berdasarkan pendekatan perhitungan kekuatan sambungan tampang dua yang dimuat pada PKKI (1961), maka besarnya rataan kekuatan atau beban per baut untuk kayu golongan II dan III masing-masing sebesar 640 dan $393 \mathrm{~kg}$. Tanpa memerhatikan diameter baut jika dibandingkan dengan golongan II (bangkirai, kapur dan punak) rataan beban per baut hasil penelitian ini untuk sesaran $5 \mathrm{~mm}$ sedikit lebih tinggi $(693 \mathrm{~kg})$ namun jauh lebih rendah $(283 \mathrm{~kg})$ untuk sesaran $1,5 \mathrm{~mm}$. Sebaliknya kelompok kayu golongan III (bintangur dan meranti) rataan beban per baut hasil penelitian ini (sesaran $5 \mathrm{~mm}$ ) jauh lebih tinggi $(693 \mathrm{~kg}$ ) namun sedikit lebih rendah $(283 \mathrm{~kg})$ untuk sesaran 1,5 $\mathrm{mm}$ bila dibandingkan dengan beban per baut yang diatur dalam PKKI (1961) untuk golongan III (393 kg). Kelompok kayu bangkirai yang termasuk kedalam golongan II menurut PKKI (1961) jika didasarkan pada sesaran sambungan $5,0 \mathrm{~mm}$ (beban rusak) memiliki rataan beban per baut sedikit lebih tinggi (1,08 kali), yaitu masing-masing 532 $\mathrm{kg}$ (diameter baut $6,4 \mathrm{~mm}), 779 \mathrm{~kg}(7,9 \mathrm{~mm})$ dan $770 \mathrm{~kg}(9,5 \mathrm{~mm})$ dibandingkan nilai disain menurut ketentuan PKKI (1961), yaitu 484, 652, dan 784 kg untuk diameter baut yang sama. Apabila nilai disain didasarkan pada sesaran 1,5 mm (diasumsikan masih dibawah batas proporsional) maka rataan beban per baut kayu golongan II penelitian ini (283 $\mathrm{kg}$ ) masih lebih tinggi sekitar 1,22 kali dari nilai disain menurut PKKI (1961) yaitu $233 \mathrm{~kg}$. Demikian halnya dengan kayu bintangur dan meranti yang termasuk golongan III, rataan beban per bautnya (283 kg) lebih tinggi sekitar 1,98 kali dari nilai disain menurut PKKI (1961) yang hanya sekitar 143 kg. 
Kekuatan kayu sengon menurut klasifikasi kelas kuat PKKI (1961) tergolong kelas V (sangat rendah) sehingga tidak memadai untuk digunakan sebagai balok atau batang sambung dengan menggunakan alat sambung baut.

\section{KESIMPULAN}

Rataan kadar air kayu sengon, meranti, bintangur, dan bangkirai relatif sama (sekitar 12 $\%$ ) sedangkan kayu kapur dan punak mempunyai sedikit lebih tinggi, yaitu sekitar $14 \%$. Sebaliknya rataan kerapatan enam jenis kayu sangat bervariasi berturut-turut dari tertinggi kayu bangkirai $0,82 \mathrm{~g}$ $\mathrm{cm}^{-3}$, disusul kayu kapur $0,82 \mathrm{~g} \mathrm{~cm}^{-3}$, punak $0,78 \mathrm{~g}$ $\mathrm{cm}^{-3}$, bintangur $0,54 \mathrm{~g} \mathrm{~cm}^{-3}$, meranti $0,36 \mathrm{~g} \mathrm{~cm}^{-3}$ dan terendah kayu sengon $0,26 \mathrm{~g} \mathrm{~cm}^{-3}$.

Beban total dan beban per baut sambungan geser ganda dengan alat sambung baut dipengaruhi oleh faktor jenis kayu, diameter baut, dan jumlah baut. Terdapat kecenderungan umum bahwa semakin tinggi BJ atau kerapatan kayu maka semakin tinggi pula beban total dan beban per baut sambungan geser ganda untuk masing-masing sesaran. Disamping itu ada kecenderungan yang sangat kuat pada pemakaian jumlah baut dimana semakin banyak bautyang digunakan maka semakin tinggi pula beban total disatu sisi namun pada sisi lain semakin menurun beban per bautnya menurut masing-masing diameter baut. Penggunaan 10 buah baut berdiameter $7,9 \mathrm{~mm}$ pada sambungan geser ganda untuk hampir semua jenis kayu menghasilkan rataan beban total paling tinggi dibandingkan baut berdiameter lainnya baik pada sesaran 1,5 maupun $5 \mathrm{~mm}$. Pada sesaran sambungan yang sama beban per baut tertinggi tetap diperoleh dari baut berdiameter $7,9 \mathrm{~mm}$ tetapi dengan pemakaian 4 buah baut untuk hampir semua jenis kayu, kecuali kayu punak dan bintangur nilai tertinggi beban per bautnya diperoleh dari 6 buah baut. Dengan demikian kayu bangkirai, kapur, punak, bintangur dan meranti dapat digunakan sebagai batang utama pada sambungan geser ganda dengan baut diameter 6,4; 7,9 dan 9,5 mm karena mempunyai kekuatan atau beban per baut sebagai nilai disain yang lebih tinggi 1,2 kali (golongan II) dan 2,0 kali (golongan III) dari kekuatan sambungan yang diatur menurut PKKI (1961).

\section{DAFTAR PUSTAKA}

[AWC] American Wood Council. 2005. National Design Specification: For Wood Construction, ASD/LRFD. American Forest \& Paper Association, 2005 Edition. Washington DC 20336.

[ASTM] American Society for Testing and Materials. 2002. Standard Test Methods for Mechanical Fastener in Wood. ASTM D 5652-95., Philadelphia, PA.

[ASTM] American Society for Testing and Materials. 2005. Annual Book of ASTM Standards Volume 04-10, Wood. D143 (2005). Standard Test Methods for Small Clear Specimen of Wood. USA.

Beery, W.H., G. Ifju and T.E. McLain. 1983. Qualitative Wood Anatomy-Relating Anatomy to Transverse Tensile Strength. Wood Fiber Sci. 15:395-407.

Bleron, L. and G. Duchanois. 2006. Anggle to the Grain Embedding Strength Concerning Dowel Type Fasteners. Forest Product Journal; 56,3; ABI/INFORM Global pg.44.

Bowyer, J. L., R. Shmulsky and J. G. Haygreen. 2003. Forest Products and Wood Science, An Introduction. USA: The Lowa State University Press.

Breyer, D.E., K.J. Fridley., K.E. Cobean and D.G. Pollock. 2007. Design of Wood Structures, ASD/LRFD. RR Donnelley. McGraw-Hill Professional, Two Penn Plaza, New York, NY 10121-2298.

Courney, T.H. 2000. Mechanical Behaviour of Materials. Chapt. 14:686-714. McGraw-Hill International Editions.

Haygreen, J.G. and J.L. Bowyer, 1993. Forest Product and Wood Science, An Introduction. lowa State University Press. Ames, lowa.

Nurhasanah. 2010. Kekuatan Sambungan Tarik Double Shear Tiga Jenis Kayu pada Berbagai Sesaran Menurut Diameter dan Jumlah Baut [Skripsi]. Departemen Hasil Hutan, Fakultas Kehutanan IPB. Bogor. Tidak Diterbitkan.

Panshin, A.J. and C. De Zeeuw. 1964. Textbook of Wood Technology 4th Ed. New York: McGraw Hill.

[PKKI]. Peraturan Konstruksi Kayu Indonesia. 1961. Lembaga Penyelidikan Masalah Bangunan, Departemen Pekerjaan Umum dan Tenaga Listrik. Yayasan Normalisasi Indonesia. Bandung.

Sadiyo, S. 1989. Pengaruh Kombinasi Jenis Kayu dan Jenis Perekat Terhadap Sifat Fisis dan Mekanis Panel Diagonal Lambung Kapal [Tesis]. Bogor: Fakultas Pascasarjana. Institut Pertanian Bogor. Bogor.

Sadiyo, S. 2010. Perilaku Kekuatan Sambungan Geser Ganda Batang Kayu dengan Paku Majemuk Berpelat Sisi Baja akibat Beban Uni-Aksial Tekan [Disertasi]. Bogor: Fakultas Pascasarjana, Institut Pertanian Bogor. 
Sadiyo, S. 2011. Analisis Sesaran pada Batas Proporsional dan Beban Maksimum Sambungan Geser Ganda Batang Kayu dengan Paku Majemuk Berpelat Sisi Baja Akibat Beban Uni-Aksial Tekan. Jurnal Teknik Sipil. Vol. 18 No. 2: 127-135. Institut Teknologi Bandung. Bandung.

Sholihin. 2011. Kekuatan Sambungan Baut Double Shear Berpelat Sisi Baja pada Kayu Sengon, Bintangur dan Kapur Menurut Berbagai Sesaran [Skripsi]. Departemen Hasil Hutan, Fakultas Kehutanan IPB. Bogor. Tidak Diterbitkan.

Skaar, C. 1972. Water in Wood. Syracuce Wood Science Series. University Press New York.

Sriyanto. 2009. Kekuatan Sambungan Tarik Double Shear Balok $\urcorner$ Kayu-Pelat Baja Menurut Diameter dan Jumlah Paku pada Sesaran Tertentu [Skripsi]. Departemen Hasil Hutan, Fakultas Kehutanan IPB. Bogor. Tidak Diterbitkan.

Surya, P.E. 2002. Aneka Cara Menyambung Kayu. Jakarta : Puspa Swara.
Tular dan Idris. 1981. Sekilas Mengenai Struktur Bangunan Kayu di Indonesia. Proceeding Lokakarya Standarisasi Kayu Bangunan. Departemen Hasil Hutan, Institut Pertanian Bogor. Bogor.

Tsoumis, G. 1991. Science and Technology of Wood (Structure, Properties, Utilization). New York: Van Nostrand Reinhold.

Suryokusumo,S., S. Sadiyo., Marzufli., A.A. Bismo and A.Ch. Setyo.1980. Sistim Keteknikan Kayu. Studi Sambungan Gang Nail dan Sambungan Paku. Fakultas Kehutanan, Institut Pertanian Bogor. Bogor.

Wirjomartono, S. 1977. Konstruksi Kayu, Jilid I, Cetakan VI, Penerbit Fakultas Teknik, Universitas Gajah Mada, Yokyakarta

Yap, K.H.F. 1997. Konstruksi Kayu. Cetakan kedelapan. Bandung : CV. Trimitra Mandiri. 